九州大学学術情報リポジトリ

Kyushu University Institutional Repository

\title{
Highly Microporous Activated Carbon from Acorn Nutshells and its Performance in Water Vapor Adsorption
}

Chairunnisa

Department of Energy and Environmental Engineering, Interdisciplinary Graduate School of Engineering Sciences, Kyushu University

\section{K. Thu}

Department of Energy and Environmental Engineering, Interdisciplinary Graduate School of Engineering Sciences, Kyushu University

\section{T. Miyazaki}

Department of Energy and Environmental Engineering, Interdisciplinary Graduate School of Engineering Sciences, Kyushu University

Nakabayashi, Koj i

Advanced Device Materials, Institute for Material Chemistry and Engineering, Kyushu University 他

https://doi.org/10.5109/4372285

出版情報：Evergreen. 8 (1)，pp.249-254，2021-03. 九州大学グリーンテクノロジー研究教育センター バージョン：

権利関係 : 


\title{
Highly Microporous Activated Carbon from Acorn Nutshells and its Performance in Water Vapor Adsorption
}

\author{
Chairunnisa $^{1, *}$, K. Thu ${ }^{2}$, T. Miyazaki ${ }^{3}$, K. Nakabayashi ${ }^{4}$, J. Miyawaki ${ }^{5}$, A. T. Wij \\ ayanta $^{6}$, F. Rahmawati ${ }^{7}$ \\ 1,2,3 Department of Energy and Environmental Engineering, IGSES, Kyushu University, Japan \\ 1,2,3 International Institute for Carbon-Neutral Energy Research, Kyushu University, Japan \\ 4,5 Advanced Device Materials, Institute for Material Chemistry and Engineering, Kyushu University, Japan \\ ${ }^{1}$ Department of Science, Sumatera Institute of Technology, Lampung, 35365, Indonesia \\ ${ }^{6}$ Department of Mechanical Engineering, Universitas Sebelas Maret, Jawa Tengah, 57126, Indonesia \\ ${ }^{7}$ Department of Chemistry, Universitas Sebelas Maret, Jawa Tengah, 57126, Indonesia
}

*E-mail: chairunnisa.365@s.kyushu-u.ac.jp

(Received September 24, 2020; Revised March 25, 2021; accepted March 26, 2021).

\begin{abstract}
The green preparation of microporous activated carbon using acorn nutshell with different production conditions was studied. The heating rate and nitrogen flow rate were controlled during preparation. The effect of those conditions on the surface properties and water adsorption performance was observed. According to the results, the total surface area of acorn nutshells-based activated carbon can reach up to $993 \mathrm{~m}^{2} / \mathrm{g}$ with $90 \%$ microporosity and a total pore volume of 0.49 $\mathrm{cm}^{3} / \mathrm{g}$. The water adsorption uptake under $P / P_{0}=0.9$ of prepared material is up to $0.39 \mathrm{~g} / \mathrm{g}$. This study found that acorn nutshell shows potential performance as a precursor for producing highly microporous activated carbon, which might be suitable for water vapor adsorption.
\end{abstract}

Keywords: activated carbon; microporous; acorn nutshells; water adsorption; steam activation

\section{Introduction and background}

The unique physical and chemical properties of activated carbon make it an important material for various fields. Activated carbon has been primarily utilized in adsorption applications such as liquid-based ${ }^{1,2)}$ and gas adsorption ${ }^{3), 4}$. The adsorption application by activated carbon not only for the air purification objective, but also for cooling ${ }^{5), 6)}$, dehumidification ${ }^{7)}$, and even for thermal storage applications. Different methods have been developed to prepare activated carbons with various properties. Several raw materials have been used as activated carbon's precursors, such as coal ${ }^{8), 99}, \operatorname{tar}^{10)}$, and biomass waste ${ }^{11), 12}$. Among those precursors, it is believed that biomass waste is a low-cost and green precursor, and its utilization might reduce solid waste and increase the waste's economic value.

In the production of activated carbon, the activation step is necessary to remove molecules that clogged the exhibited pores and develop them. The activation process is classified into chemical and physical activation. Chemical activation is conducted by using salts ${ }^{13)}$, bases ${ }^{3)}$, or acid ${ }^{14)}$. Physical activation is proceeded by using some gasses such as $\mathrm{CO}_{2}{ }^{15)}$, air ${ }^{16), 17)}$, or steam ${ }^{18), 19}$. Physical activation is an environmentally benign method compare with chemical activations due to unnecessary posttreatment such as washing, which significantly reduced the wastewater produced from the activation step.

In this study, the activated carbon was produced from Acorn nutshell to develop biomass waste-based activated carbon with suitable properties for water vapor adsorption. It is worth noting that activated carbon naturally has an almost hydrophobic surface. However, due to the small amount of active hydrophilic functional groups available on the surface of activated carbon, this material has the ability to adsorb the water vapor ${ }^{20}$. Compared with the commercial desiccant materials, such as silica gels and other alumina-silica materials, activated carbon has different water vapor adsorption properties, and one of the most advantages own by it is the easiness of water vapor to be desorbed from the adsorbent, which thus hopefully lowering the regeneration temperature of the material.

Microporosity plays an essential part in the ability of activated carbon for water vapor adsorption application. One way to produce activated carbon with high amounts of micropores is by physical activation, such as steam activation. It was reported before that steam can produce high microporosity of activated carbon ${ }^{11}$. Mamani et al. ${ }^{21)}$ reported that activated carbon from lingo-cellulosic biomass prepared by steam activation has $74 \%$ microporosity. Furthermore, Heo et al. ${ }^{22)}$ produced high microporous activated from cellulose fibers by using steam activation. Not only the number of micropores is 
essential, but the size of the micropore itself should also be controlled since the adsorption of water vapor strongly depends on the size of micropore ${ }^{23)}$. Controlling the microporosity of activated carbon prepared by steam activation is challenging due to the rapid reaction between steam and the wall of carbon material. Therefore, in this study, the activated carbon using steam activation was prepared, and the microporosity of the prepared material was controlled by using different preparation conditions. Then, the performance of prepared activated carbon for water vapor adsorption was studied under different relative pressures.

\section{Methodology}

\subsection{Materials and sample preparation}

Acorn nutshell was dried at $100^{\circ} \mathrm{C}$ overnight and ground before carbonization. About $11 \mathrm{~g}$ of dried powdered-nutshell was put into an alumina crucible (placed inside the furnace equipped with temperature controller) and heated using different heating rate: $5^{\circ} \mathrm{C} / \mathrm{min}, 10^{\circ} \mathrm{C} / \mathrm{min}$, and $15^{\circ} \mathrm{C} / \mathrm{min}$ from $25^{\circ} \mathrm{C}$ to $900^{\circ} \mathrm{C}$ under different $\mathrm{N}_{2}$ stream $(100 \mathrm{cc} / \mathrm{min} ; 200 \mathrm{cc} / \mathrm{min} ; 400$ $\mathrm{cc} / \mathrm{min}$; and $500 \mathrm{cc} / \mathrm{min}$ ). The materials produced from the carbonization step were labeled as $\mathrm{C}$. The $\mathrm{C}$ prepared from different carbonization conditions was then activated by using steam activation. The activation was conducted using the same system with different heating and $\mathrm{N}_{2}$ flow rate. The activation was done using a temperature of $900^{\circ} \mathrm{C}$ for 10 minutes to avoid excess burn-off. The details of preparation conditions were presented in Table 1 .

Table 1. Preparation conditions

\begin{tabular}{|c|c|c|c|c|}
\hline \multirow{2}{*}{ Samples } & \multicolumn{2}{|c|}{$\begin{array}{c}\text { Carbonization } \\
\text { condition }\end{array}$} & \multicolumn{2}{|c|}{$\begin{array}{l}\text { Activation } \\
\text { condition }\end{array}$} \\
\hline & $\begin{array}{c}\text { HR } \\
\left({ }^{\circ} \mathrm{C} / \mathrm{min}\right)\end{array}$ & $\begin{array}{c}\text { NR } \\
\text { (cc/min) }\end{array}$ & $\begin{array}{c}\text { HR } \\
\left({ }^{\circ} \mathrm{C} / \mathrm{min}\right)\end{array}$ & $\begin{array}{c}\text { NR } \\
\text { (cc/min) }\end{array}$ \\
\hline $\mathrm{C} 1$ & 5 & 200 & \multirow{3}{*}{\multicolumn{2}{|c|}{ Without activation }} \\
\hline $\mathrm{C} 2$ & 10 & 200 & & \\
\hline $\mathrm{C} 3$ & 15 & 200 & & \\
\hline $\mathrm{AC} 1$ & 5 & 200 & 5 & 200 \\
\hline $\mathrm{AC} 2$ & 10 & 200 & 10 & 200 \\
\hline $\mathrm{AC} 3$ & 15 & 200 & 15 & 200 \\
\hline $\mathrm{C} 4$ & 15 & 100 & \multirow{3}{*}{\multicolumn{2}{|c|}{ Without activation }} \\
\hline $\mathrm{C} 5$ & 15 & 400 & & \\
\hline $\mathrm{C} 6$ & 15 & 500 & & \\
\hline $\mathrm{AC} 4$ & 15 & 100 & 15 & 100 \\
\hline AC5 & 15 & 400 & 15 & 400 \\
\hline AC6 & 15 & 500 & 15 & 500 \\
\hline $\mathrm{AC7}$ & 5 & 200 & 15 & 200 \\
\hline
\end{tabular}

*HR $=$ heating rate, $\mathrm{NR}=\mathrm{N}_{2}$ flor rate, $\mathrm{C}=$ char, $\mathrm{AC}=$ activated carbon

\subsection{Characterization}

The $\%$ yield of $\mathrm{C}$ and $\mathrm{AC}$ was calculated after carbonization and activation steps using the equation below:

Yield $(\%)=\frac{\text { Carbon material mass }}{\text { Raw material mass }} \times 100 \%$

The thermal degradation of acorn nutshells was measured using EXSTAR TG/DTA6000, SII at $25^{\circ} \mathrm{C}$ to $900^{\circ} \mathrm{C}$ with $\mathrm{N}_{2}$ flow rate of $200 \mathrm{cc} / \mathrm{min}$ and a heating rate of $10^{\circ} \mathrm{C} / \mathrm{min}$. The pore properties were analyzed using nitrogen adsorption-desorption at 77K (NOVA 3200e Quantachrome, USA). The samples were first degassed at $120^{\circ} \mathrm{C}$ for more than $5 \mathrm{~h}$ to remove the adsorbed gas before measurement. The obtained $\mathrm{N}_{2}$ adsorption isotherms were used to analyze the pore properties of activated carbon. DFT method provided by Quantachrome was utilized to determine the total surface area $\left(A_{t o t}\right)$, micropore surface area $\left(\mathrm{S}_{\mathrm{mi}}\right)$, total pore volume $\left(\mathrm{V}_{\text {tot }}\right)$, and micropore volume $\left(\mathrm{V}_{\text {mic }}\right)$ of carbon materials.

The water vapor uptake of activated carbons was measured by a magnetic suspension adsorption unit of type MSB-VG-S2 supplied by Belsorp Japan, Inc at $30^{\circ} \mathrm{C}$. The weight measurement resolution is $10 \mu \mathrm{g}$ with a relative error of $\pm 0.002 \%$ of reading. Julabo thermal stability is $\pm 0.01^{\circ} \mathrm{C}$, and fluid density accuracy is \pm 0.02 $\mathrm{kg} / \mathrm{m}^{3}$. Before the measurements, the materials were degassed at $120^{\circ} \mathrm{C}$ for $\geq 5 \mathrm{~h}$ in vacuo $(<0.133 \mathrm{~Pa})$. Adsorption-desorption tests were conducted continuously. The pressure of water vapor was controlled by setting different temperatures of the vapor source. The adsorption pressure was from $0.6 \mathrm{kPa}$ to $3.7 \mathrm{kPa}$, while the desorption was from $3.7 \mathrm{kpa}$ to $0.6 \mathrm{kPa}$.

\section{Results and Discussion}

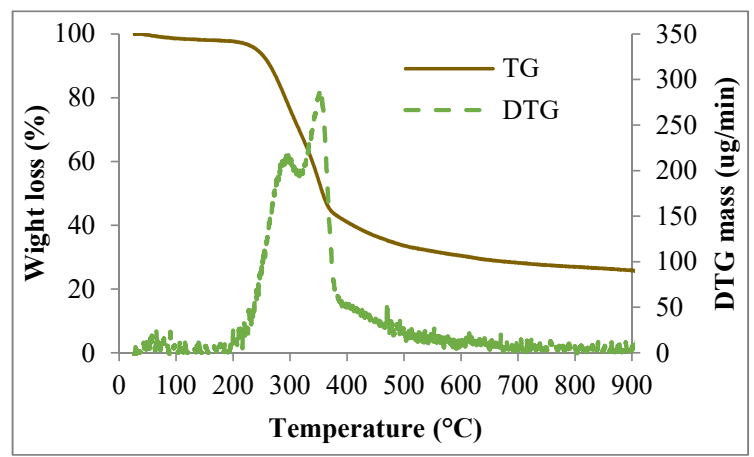

Fig. 1: TGA curve of raw material $(\mathrm{TG}=$ Thermogravimetry; DTG $=$ Derivative Thermogravimetry)

The study of thermal degradation of raw material is essential as a preliminary study before selecting activated carbon precursors and deciding the preparation conditions. From Fig. 1, there is a slow rate of mass loss in the temperature range up to $200^{\circ} \mathrm{C}$, which is due to the release of moisture. The mass loss in the temperature range up to $200^{\circ} \mathrm{C}$ to $500^{\circ} \mathrm{C}$ may cause by the degradation of cellulose, hemicellulose, and lignin into a smaller organic compound and released during heating treatment ${ }^{24}$. The mass loss then became lower when the temperature 
increased up to $900^{\circ} \mathrm{C}$, which might occur due to the hardness and complexness of the lignin structure to be degraded.

(a)

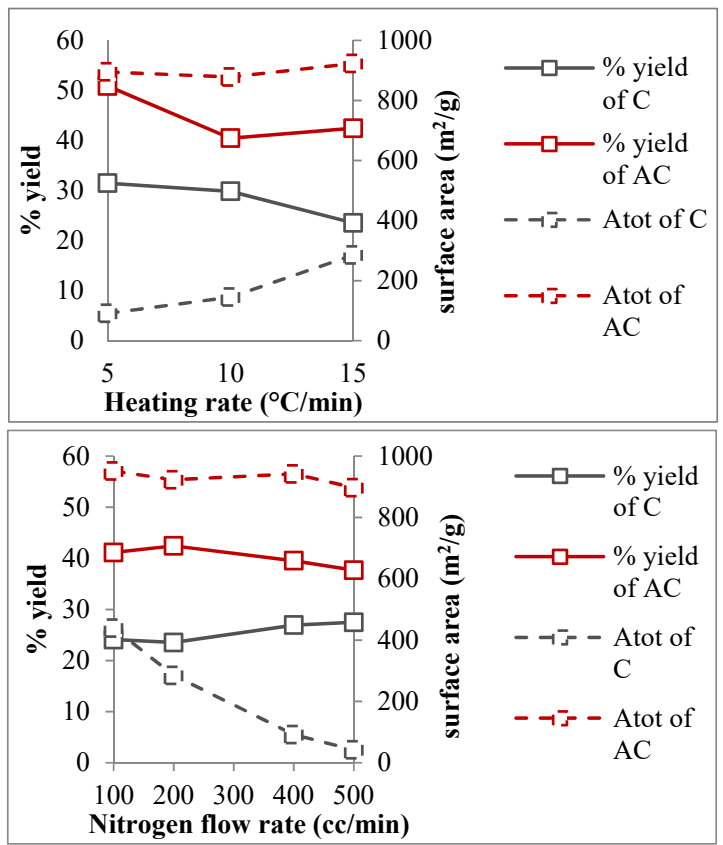

Fig. 2: The effect of heating rate (a) and nitrogen flow rate (b) on the \%yield and Atot of carbon materials.

The effect of heating rate and nitrogen flow rate on the $\%$ yield and surface area of carbon materials was shown in Fig. 2. In general, it can be observed that there is an opposite relationship between the \% yield and total surface area. The preparation process, which produced a low $\%$ yield, generates the carbon material with a higher total surface area.

According to Fig. 2a, the faster the heating rate used for carbonization and activation, the lower \% yield of the material produced. It was reported that a faster heating rate degrades more organic molecules into tar and light gases $^{25,26)}$, which was indicated by the decrease of $\%$ carbonization yield. The faster heating rate during carbonization also increased the $\mathrm{A}_{\text {tot }}$ of produced chars. For activation, a heating rate of $5^{\circ} \mathrm{C} / \mathrm{min}$ produced $\mathrm{AC}$ with the highest \% yield. The \% yield decreased when $10^{\circ} \mathrm{C} / \mathrm{min}$ was used and raised again when $15^{\circ} \mathrm{C} / \mathrm{min}$ was utilized for activation.

On the other hand, Fig. $2 \mathrm{~b}$ shows the relationship between $\mathrm{N}_{2}$ flow rate with \% yield and $\mathrm{A}_{\text {tot }}$ of carbon materials produced with the same heating rate $\left(15^{\circ} \mathrm{C} / \mathrm{min}\right)$. In this study, $\mathrm{N}_{2}$ gas was used to keep the inert atmosphere in pyrolysis $^{27)}$ and as a sweep gas to remove the char surface's volatile product and reduce the secondary reaction such as re-polymerization and recondensation ${ }^{28)}$. For that reason, during carbonization (pyrolysis), the higher the $\mathrm{N}_{2}$ flow rate used, the bigger \% yield of char was obtained. Different $\mathrm{N}_{2}$ flow rates gave different tendencies on the activation step. The $200 \mathrm{cc} / \mathrm{min}$ of nitrogen flow rate resulted in $\mathrm{AC}$ with the biggest \% yield while the flow rate more than that, resulting in a lower $\%$ yield. The effect of $\mathrm{N}_{2}$ flow rate on the surface area of $\mathrm{AC}$ also different with $\mathrm{C}$. AC produced by $100 \mathrm{cc} / \mathrm{min}$ and $400 \mathrm{cc} / \mathrm{min}$ of $\mathrm{N}_{2}$ flow rate shows the ACs with the highest surface area.

The effect of preparation conditions on activated carbons' porosity was reflected on the $\mathrm{N}_{2}$ adsorption at 77 $\mathrm{K}$ in Fig. 3. The $\mathrm{N}_{2}$ adsorption on acorn nutshell-based chars and activated carbon follows type I of the IUPAC classification with hysteresis type $\mathrm{H} 4$, which is characteristics of microporous material with slit-like pores $^{29)}$. Fig. 3a represents the effect of heating rate while Fig. $3 \mathrm{~b}$ shows the effect of $\mathrm{N}_{2}$ flow rate on the porosity of chars and activated carbons. Based on the $\mathrm{N}_{2}$ sorption uptakes on each material, it can be observed that more $\mathrm{N}_{2}$ adsorbed on activated carbons than chars which can be assumed that activated carbon contains more pores than char. The big carbon molecules were degraded during carbonization, producing tar, releasing some volatile compounds and gasses. On the other hand, activation is the process when the tarry products that clogged the pores of char were removed by the reaction between them and the activating agent (steam) under high temperature, reducing the mass of materials, creating the new pores, and enlarging the existed pores. Thus, the carbon materials that have lower mass ( $\%$ yield) possess a bigger surface area.

(a)

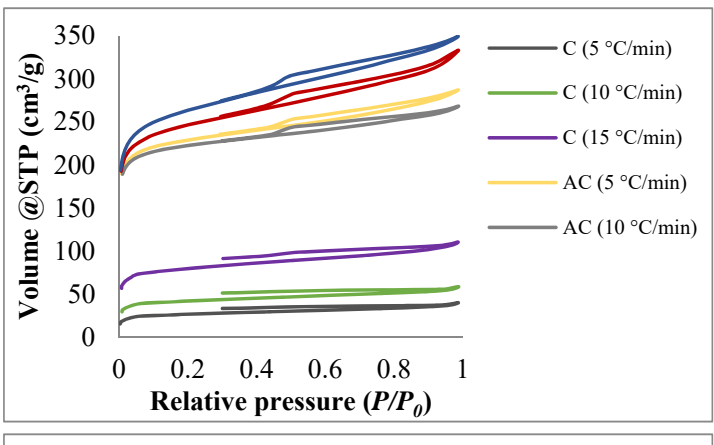

(b)

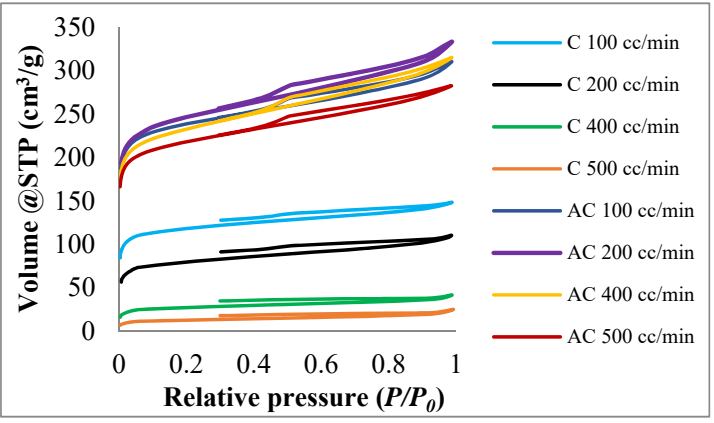

Fig. 3: $\mathrm{N}_{2}$ adsorption isotherm on biochar and activated carbon prepared by different (a) heating rate, (b) $\mathrm{N}_{2}$ gas flow rate 
Table 2. Pore properties of Acorn nutshells based carbon materials

\begin{tabular}{|c|c|c|c|c|c|}
\hline \multirow{2}{*}{ Samples } & \multicolumn{5}{|c|}{ Pore Properties } \\
\cline { 2 - 6 } & $\begin{array}{c}\mathbf{A}_{\text {tot }} \\
\left(\mathbf{m}^{2} / \mathbf{g}\right)\end{array}$ & $\begin{array}{c}\mathbf{A}_{\text {mic }} \\
\left(\mathbf{m}^{2} / \mathbf{g}\right)\end{array}$ & $\begin{array}{c}\mathbf{V}_{\text {tot }} \\
\mathbf{( c m}^{\mathbf{3}} \\
\mathbf{/ g})\end{array}$ & $\begin{array}{c}\mathbf{V}_{\text {mic }} \\
\mathbf{( c m}^{\mathbf{3}} / \mathbf{g} \\
\mathbf{g})\end{array}$ & $\begin{array}{c}\mathbf{V}_{\text {mic }} \\
\mathbf{V}_{\text {tot }} \\
\mathbf{( \% )}\end{array}$ \\
\hline C1 & 91 & 90 & 0.05 & 0.05 & 100 \\
\hline C2 & 145 & 145 & 0.08 & 0.07 & 88 \\
\hline C3 & 285 & 281 & 0.18 & 0.14 & 78 \\
\hline AC1 & 895 & 885 & 0.40 & 0.36 & 90 \\
\hline AC2 & 878 & 871 & 0.37 & 0.35 & 95 \\
\hline AC3 & 923 & 881 & 0.89 & 0.38 & 43 \\
\hline C4 & 439 & 436 & 0.20 & 0.19 & 95 \\
\hline C5 & 92 & 92 & 0.05 & 0.05 & 100 \\
\hline C6 & 42 & 41 & 0.03 & 0.03 & 97 \\
\hline AC4 & 952 & 939 & 0.43 & 0.38 & 88 \\
\hline AC5 & 942 & 905 & 0.77 & 0.37 & 48 \\
\hline AC6 & 897 & 885 & 0.40 & 0.36 & 89 \\
\hline AC7 & 993 & 979 & 0.49 & 0.44 & 90 \\
\hline
\end{tabular}
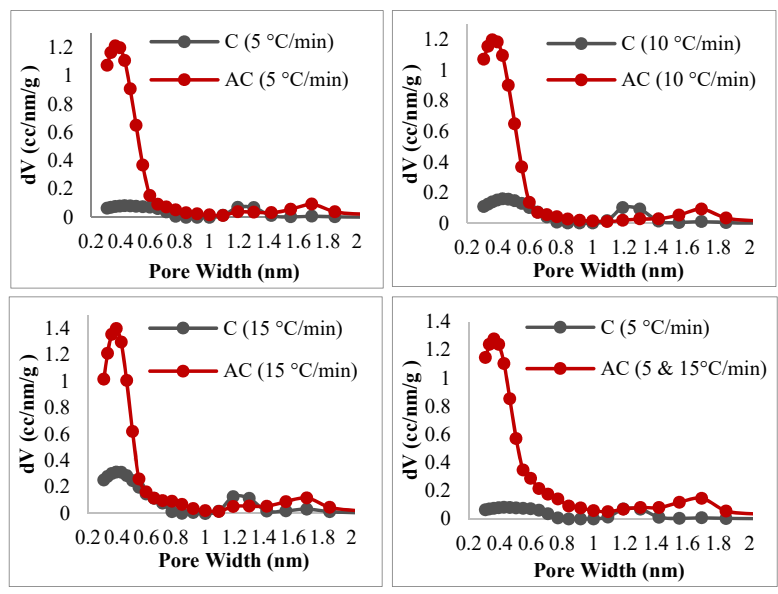

Fig. 4: Pore size distribution of acorn nutshells based carbon materials

The resume of pore properties of each material that was produced using different preparation conditions was presented in Table 2. Based on $\mathrm{N}_{2}$ adsorption on Fig. 3 and Table 2, char that produced by 100 (C4), 200 (C3), 400 (C5), and $500 \mathrm{cc} / \mathrm{min}$ (C6) of $\mathrm{N}_{2}$ flow rate has $\mathrm{A}_{\text {tot }}$ of 439 $\mathrm{m}^{2} / \mathrm{g}, 285 \mathrm{~m}^{2} / \mathrm{g}, 92 \mathrm{~m}^{2} / \mathrm{g}, 42 \mathrm{~m}^{2} / \mathrm{g}$, respectively. From here, it can be claimed that the higher the $\mathrm{N}_{2}$ flow rate utilized for carbonization, the lower the surface area of char was produced. For activation, the tendency is slightly different. The highest surface area of activated carbon was obtained when using $\mathrm{N}_{2}$ flow rate of $200 \mathrm{cc} / \mathrm{min}$ with $5{ }^{\circ} \mathrm{C} / \mathrm{min}$ of heating rate on carbonization followed by $15^{\circ} \mathrm{C} / \mathrm{min}$ of heating rate on activation.

Activated carbon is known for the heterogeneity of its pore size, which is classified into micropores $(<2 \mathrm{~nm})$, mesopores $(2 \mathrm{~nm}-50 \mathrm{~nm})$, and macropores $(>50 \mathrm{~nm})$. From the pore size distributions in Fig. 4, the chars (C) has different size of pores. After activation (AC), more micropores with a width below $0.8 \mathrm{~nm}$ were produced, which confirmed that the steam activation has the ability to produce activated carbon with high microporosity in a short duration.

In order to estimate the possible application of the synthesized activated carbons in the water vapor adsorption-based application, the adsorption isotherms of water vapor on the surface of activated carbon at $30^{\circ} \mathrm{C}$ on prepared activated carbons were measured. Activated carbon that has been used for this adsorption study are $\mathrm{AC} 3, \mathrm{AC} 4, \mathrm{AC} 7$, which have the highest $\mathrm{V}_{\text {mic }}$ among other prepared carbon materials. Figure 5 represents the adsorption-desorption isotherm on the carbon materials with full dots are for adsorption while empty dots are for desorption.

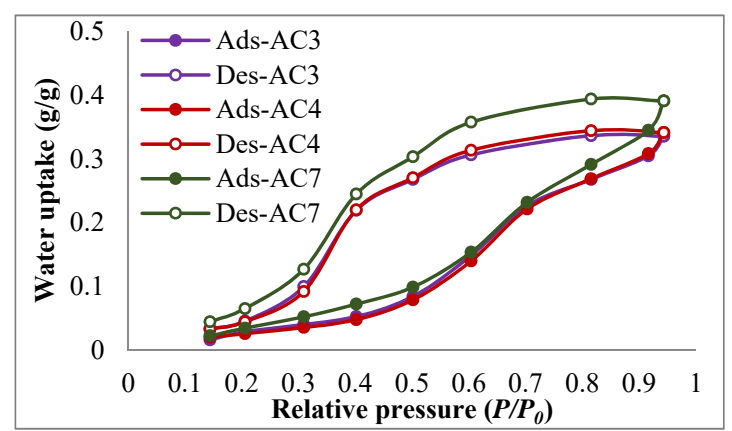

Fig. 5: Adsorption isotherm of water vapor onto activated carbons

According to Fig 5, the adsorption isotherms of water vapor onto activated carbon increases with relative pressure $\left(P / P_{0}\right)$. The water adsorption on $\mathrm{AC} 3, \mathrm{AC} 4$, and AC7 has type $\mathrm{V}$ isotherm, strongly related to the adsorption of water vapor on slightly hydrophilic materials like activated carbon ${ }^{30}$. Based on Fig. 5, it can be noticed that there is a steep water vapor adsorption isotherm on $P / P_{0}=0.4$ to $P / P_{0}=0.7$, which is associated with water clusters arrangement, leading to the micropore filling ${ }^{31)}$.

According to previous research, water vapors' adsorption on activated carbons occurs only by a physical process with weak interaction between the surface of activated carbon and water vapor. The adsorption is started by the hydrogen bonding formation between available hydrophilic functional groups of activated carbon and water molecules. These attached water molecules then perform as the center of adsorption for the next coming water vapor. The water molecules then form clusters through hydrogen bonding between water-water molecules, and the clusters are located around the primary adsorption centers. At higher $P / P_{0}$, the clusters form bridges across the pores, and when the space between clusters is too close, the increasing vapor pressure leading to the pore filling ${ }^{31), 32)}$.

In this study, the amount of water vapor adsorbed onto $\mathrm{AC} 3, \mathrm{AC} 4$, and $\mathrm{AC} 7$ at $P / P_{0} 0.9$ were $0.33 \mathrm{~g} / \mathrm{g}, 0.34 \mathrm{~g} / \mathrm{g}$, and $0.39 \mathrm{~g} / \mathrm{g}$, respectively. Water uptake on $\mathrm{AC} 3$ was close with AC4 due to their similar characteristics. Only 
different $\mathrm{N}_{2}$ flow rates were used during carbonization and activation, AC3 using $200 \mathrm{~N}_{2} / \mathrm{min}$ and AC4 using 100 $\mathrm{N}_{2} /$ min. Both processes produced similar \% yield and total surface area, resulting in similar water adsorption uptake. The adsorption value near saturation pressure $\left(P / P_{0}=0.9\right)$ showed a strong relationship between the amounts of water uptake with $\mathrm{V}_{\text {mic }}$ of $\mathrm{AC} 3, \mathrm{AC} 4$, and $\mathrm{AC} 7$, which are $0.38 \mathrm{~cm}^{3} / \mathrm{g}, 0.38 \mathrm{~cm}^{3} / \mathrm{g}$, and $0.44 \mathrm{~cm}^{3} / \mathrm{g}$, respectively. Therefore, it is assumed that the water adsorption mechanism on acorn nutshells-based activated carbon is strongly related to the micropore filling mechanism ${ }^{33)}$.

Based on the water vapor adsorption behavior on acorn nutshell-based-activated carbon, it can be assumed that those materials might have promising performance in removing water vapor at the range of $P / P_{0}=0.7$ to 1 . Therefore, those prepared materials may be suitable to process inlet air with high humidity, such as agricultural products storage ${ }^{34)}$ or dehumidification systems in summer and humid places.

\section{Conclusion}

Different heating and nitrogen flow rate effects on activated carbon's physical properties were investigated in this work. According to the results, the heating and the nitrogen flow rate strongly affected the physical properties of the materials. It is found that the surface area of produced activated carbon was from $878 \mathrm{~m}^{2} / \mathrm{g}$ to $993 \mathrm{~m}^{2} / \mathrm{g}$ with a micropore volume range from $0.3 \mathrm{~cm}^{3} / \mathrm{g}$ to 0.4 $\mathrm{cm}^{3} / \mathrm{g}$. The water adsorption capacity of represented material was also measured using $P / P_{0}=0.1$ to $P / P_{0}=0.9$. Based on the water sorption data, the materials' water uptake reaches the maximum value at near saturation pressure. The maximum water vapor adsorption amount onto $\mathrm{AC} 3, \mathrm{AC} 4$, and $\mathrm{AC} 7$ at $30^{\circ} \mathrm{C}$ were $0.33 \mathrm{~g} / \mathrm{g}, 0.34 \mathrm{~g} / \mathrm{g}$, and $0.39 \mathrm{~g} / \mathrm{g}$, respectively, making these three materials may suitable for the removal of water vapor under high humidity condition.

\section{Acknowledgments}

The study was supported by JSPS Bilateral Programs Joint Research Projects (DG-RSTHE, Indonesia).

\section{References}

1) M.U. Dural, L. Cavas, S.K. Papageorgiou, and F.K. Katsaros, "Methylene blue adsorption on activated carbon prepared from posidonia oceanica (1.) dead leaves: kinetics and equilibrium studies," Chem. Eng. J., $\quad 168 \quad$ (1) $\quad 77-85 \quad$ (2011). doi:10.1016/j.cej.2010.12.038.

2) J. Miyawaki, J. Yeh, H.S. Kil, J.K. Lee, K. Nakabayashi, I. Mochida, and S.H. Yoon, "Influence of pore size and surface functionality of activated carbons on adsorption behaviors of indole and amylase," Evergreen, 3 (2) 17-24 (2016). doi: $10.5109 / 1800868$.
3) Y. Guangzhi, Y. Jinyu, Y. Yuhua, T. Zhihong, Y. DengGuang, and Y. Junhe, "Preparation and co 2 adsorption properties of porous carbon from camphor leaves by hydrothermal carbonization and sequential potassium hydroxide activation," RSC Adv., 7 (7) 4152-4160 (2017). doi:10.1039/C6RA25303B.

4) M. Muttakin, A. Pal, K. Uddin, K. Thu, K. Ito, and B. Baran Saha, "Experimental study of co_2 adsorption kinetics onto activated carbon experimental study of co2 adsorption kinetics onto activated carbon," 4 2018-2028 (2018). doi:10.15017/1960664.

5) K. Uddin, I.I. El-Sharkawy, T. Miyazaki, B.B. Saha, and S. Koyama, "Thermodynamic analysis of adsorption cooling cycle using ethanol-surface treated maxsorb iii pairs," Evergreen, 1 (1) 25-31 (2014). doi:10.5109/1440973.

6) F. Jerai, T. Miyazaki, B.B. Saha, and S. Koyama, "Overview of adsorption cooling system based on activated carbon - alcohol pair," Evergreen, 2 (1) 3040 (2015). doi:10.5109/1500425.

7) M. Sultan, I.I. El-Sharkawl, T. Miyazaki, B.B. Saha, and S. Koyama, "Experimental study on carbon based adsorbents for greenhouse dehumidification," Evergreen, 1 (2) 5-11 (2014).

8) Y. Zheng, Q. Li, C. Yuan, Q. Tao, Y. Zhao, G. Zhang, J. Liu, and G. Qi, "Thermodynamic analysis of highpressure methane adsorption on coal-based activated carbon," Fuel, 230 (May) 172-184 (2018). doi:10.1016/j.fuel.2018.05.056.

9) Y.Zheng, Q. Li, C. Yuan, Q. Tao, Y. Zhao, G. Zhang, and J. Liu, "Influence of temperature on adsorption selectivity: coal-based activated carbon for ch4 enrichment from coal mine methane," Powder Technol., $\quad 347 \quad 42-49 \quad$ (2019). doi:10.1016/j.powtec.2019.02.042.

10) S. Gao, L. Ge, T.E. Rufford, and Z. Zhu, "The preparation of activated carbon discs from tar pitch and coal powder for adsorption of co2, ch4 and n2," Microporous Mesoporous Mater., 238 19-26 (2017). doi:10.1016/j.micromeso.2016.08.004.

11) J.F. González, S. Román, C.M. González-García, J.M. Valente Nabais, and A.L. Ortiz, "Porosity development in activated carbons prepared from walnut shells by carbon dioxide or steam activation," Ind. Eng. Chem. Res., 48 (20) 9354-9354 (2009). doi:10.1021/ie9013293.

12) O. Ioannidou, and A. Zabaniotou, "Agricultural residues as precursors for activated carbon production-a review," Renew. Sustain. Energy Rev., 11 (9) 1966-2005 (2007). doi:10.1016/j.rser.2006.03.013.

13) J. He, D. Zhang, M. Han, X. Liu, Y. Wang, Y. Li, X. Zhang, K. Wang, H. Feng, and Y. Wang, "One-step large-scale fabrication of nitrogen doped microporous carbon by self-activation of biomass for supercapacitors application," J. Energy Storage, 21 (November 2018) 94-104 (2019). 
doi:10.1016/j.est.2018.11.015.

14) T. Mahmood, R. Ali, A. Naeem, M. Hamayun, and M. Aslam, "Potential of used camellia sinensis leaves as precursor for activated carbon preparation by chemical activation with h3po4; optimization using response surface methodology," Process Saf. Environ. $\begin{array}{llll}\text { Prot., } & 109 & 548-563 & \text { (2017). }\end{array}$ doi:10.1016/j.psep.2017.04.024.

15) J. Pallarés, A. González-Cencerrado, and I. Arauzo, "Production and characterization of activated carbon from barley straw by physical activation with carbon dioxide and steam," Biomass and Bioenergy, 115 (January) 64-73 (2018). doi:10.1016/j.biombioe.2018.04.015.

16) M. Olivares-Marín, C. Fernández-González, A. MacÍas-García, and V. Gómez-Serrano, "Preparation of activated carbon from cherry stones by physical activation in air. influence of the chemical carbonisation with h2so4," J. Anal. Appl. Pyrolysis, 94 131-137 (2012). doi:10.1016/j.jaap.2011.11.019.

17) Suhas, P.J.M. Carrott, M.M.L. Ribeiro Carrott, R. Singh, L.P. Singh, and M. Chaudhary, "An innovative approach to develop microporous activated carbons in oxidising atmosphere," J. Clean. Prod., $156 \quad 549-555 \quad$ (2017). doi:10.1016/j.jclepro.2017.04.078.

18) U.S. Im, J. Kim, S.H. Lee, S. mi Lee, B.R. Lee, D.H. Peck, and D.H. Jung, "Preparation of activated carbon from needle coke via two-stage steam activation process," Mater. Lett., 237 22-25 (2019). doi:10.1016/j.matlet.2018.09.171.

19) G.M. Brito, D.F. Cipriano, M.Â. Schettino, A.G. Cunha, E.R.C. Coelho, and J.C. Checon Freitas, "One-step methodology for preparing physically activated biocarbons from agricultural biomass waste," J. Environ. Chem. Eng., 7 (3) 103113 (2019). doi:10.1016/j.jece.2019.103113.

20) T. Horikawa, S. (Johnathan) Tan, D.D. Do, K.I. Sotowa, J.R. Alcántara-Avila, and D. Nicholson, "Temperature dependence of water adsorption on highly graphitized carbon black and highly ordered mesoporous carbon," Carbon N. Y., 124 271-280 (2017). doi:10.1016/j.carbon.2017.08.067.

21) A. Mamaní, M.F. Sardella, M. Giménez, and C. Deiana, "Highly microporous carbons from olive tree pruning: optimization of chemical activation conditions," J. Environ. Chem. Eng., 7 (1) 102830 (2019). doi:10.1016/j.jece.2018.102830.

22) Y.J. Heo, and S.J. Park, "A role of steam activation on co2 capture and separation of narrow microporous carbons produced from cellulose fibers," Energy, 91 142-150 (2015). doi:10.1016/j.energy.2015.08.033.

23) J. Alcañiz-Monge, A. Linares-Solano, and B. Rand, "Mechanism of adsorption of water in carbon micropores as revealed by a study of activated carbon fibers," J. Phys. Chem. B, 106 (12) 3209-3216 (2002). doi:10.1021/jp014388b.
24) A. Malika, and A. Mohammed, "Kinetic and energy study of thermal degradation of biomass materials under oxidative atmosphere using tga , dta and dsc," Sci. Technol., 1 (5) 74-78 (2014).

25) H.S. Choi, Y.S. Choi, and H.C. Park, "Fast pyrolysis characteristics of lignocellulosic biomass with varying reaction conditions," Renew. Energy, 42 131-135 (2012). doi:10.1016/j.renene.2011.08.049.

26) M.S. Safdari, E. Amini, D.R. Weise, and T.H. Fletcher, "Heating rate and temperature effects on pyrolysis products from live wildland fuels," Fuel, 242 (January) 295-304 (2019). doi:10.1016/j.fuel.2019.01.040.

27) W.A. Wan Mahari, C.T. Chong, W.H. Lam, T.N.S.T. Anuar, N.L. Ma, M.D. Ibrahim, and S.S. Lam, "Microwave co-pyrolysis of waste polyolefins and waste cooking oil: influence of $\mathrm{n} 2$ atmosphere versus vacuum environment," Energy Convers. Manag., 171 1292-1301 doi:10.1016/j.enconman.2018.06.073.

28) D. Özçimen, and A. Ersoy-Meriçboyu, "A study on the carbonization of grapeseed and chestnut shell," Fuel Process. Technol., 89 (11) 1041-1046 (2008). doi:10.1016/j.fuproc.2008.04.006.

29) K. Stafford, W. Sing, and J. Rouquerol, "Reporting physisorption data for gas / solid systems including catalysis * reporting physisorption data for gas / solid systems with special reference to the determination of surface area and porosity," Pure Appl. Chem., 57 (January 1985) 603-619 (2016).

30) T. Horikawa, Y. Kitakaze, T. Sekida, J. Hayashi, and M. Katoh, "Characteristics and humidity control capacity of activated carbon from bamboo," Bioresour. Technol., 101 (11) 3964-3969 (2010). doi:10.1016/j.biortech.2010.01.032.

31) A.W. Harding, N.J. Foley, P.R. Norman, D.C. Francis, and K.M. Thomas, "Diffusion barriers in the kinetics of water vapor adsorption/desorption on activated carbons," Langmuir, 14 (14) 3858-3864 (1998). doi:10.1021/la971317o.

32) E.A. Müller, L.F. Rull, L.F. Vega, and K.E. Gubbins, "Adsorption of water on activated carbons: a molecular simulation study," J. Phys. Chem., 100 (4) 1189-1196 (1996). doi:10.1021/jp952233w.

33) X. Li, X. Chen, and Z. Li, "Adsorption equilibrium and desorption activation energy of water vapor on activated carbon modified by an oxidation and reduction treatment," J. Chem. Eng. Data, 55 (9) 3164-3169 (2010). doi:10.1021/je100024r.

34) M.H. Mahmood, M. Sultan, T. Miyazaki, and S. Koyama, "Desiccant air-conditioning system for storage of fruits and vegetables: pakistan preview," Evergreen, 3 (1) 12-17 (2016). doi:10.5109/1657381. 